\title{
An Examination of Relationship between Quality Municipal Services and Citizen Satisfaction in Malaysian Local Council, Batu Pahat in Perspective
}

\author{
Muhammad Umar Bello ${ }^{1,2}$, David Martin ${ }^{1}$, Rozila Kasim ${ }^{1}$, Muhammad Abubakar ${ }^{3}$, \\ Muhammad Akilu Umar ${ }^{3}$
}

${ }^{1}$ Universiti Tun Hussein Onn Malaysia

101 Parit Raja, Batu Pahat, Johor, 86400, Malaysia

${ }^{2}$ Abubakar Tafawa Balewa University

Tawafa Belewa Way, P. M. B. 0248, Bauchi, 740272, Nigeria

${ }^{3}$ Abubakar Tatari Ali Polytechnic

Ahmadu Bello Way, Bauchi, 740272, Nigeria

DOl: $10.22178 /$ pos.22-2

JEL Classification: H75, I38

Received 16.04.2017

Accepted 10.05.2017

Published online 12.05.2017

Corresponding Author: Muhammad Umar Bello, mubello78@gmail.com

(c) 2017 The Authors. This article is licensed under a Creative Commons Attribution 4.0 License (c) (1)

\begin{abstract}
This study examines the relationships that exist between quality municipal service and citizen satisfaction. This paper is, therefore, an examination of Relationship between quality Municipal Service and citizen satisfaction in Batu Pahat, Malaysia. It argues that the constitutional mandate of local council in terms of "function performance" has not been translated into reality in many occasions. Hypothesis was postulated for the study. The methodology adopted is quantitative in nature, 100 questionnaires were administered and 89 were retrieved. Systematic random sampling technic was used to retrieve the respondents' responses. This study applies SPSS statistical tests and AMOS version 23 and Structural Equation Modeling (SEM) software was used for further analysis. The relationship between these two constructs was then evaluated. The findings in this paper are that quality municipal services have direct effect on citizen satisfaction. The paper shows that, on average quality municipal service enhanced citizen satisfaction. The paper has developed valid and reliable constructs that can be used to measure the effect of quality municipal services on citizen satisfaction with municipal council service delivery. Thus, the paper concludes and recommends that municipal council must attempt to overcome the challenges that have by-passed their performance. The study recommends that there is needs for local municipal to strategies to makes the local council more robust for enhancing the lives of inhabitants and to foster good relationship between the management and local people in the study area. The study also gives recommendation to municipal council to strategies on other factors to enhance citizen welfare.
\end{abstract}

Keywords: government; municipal services; local community and citizen satisfaction.

\section{Introduction}

Local government are perceived as cornerstone for general community development [4]. The importance of local government cannot be over emphasized it will stem from increasing role in local development and sustainable services. Local governments are the lower level of government in Malaysia. They are mandated with providing municipal service for local communities. However, successful local government has been identified as essential to meet the sustainable development goals, which implies a stronger role of local authorities and municipalities in local development [9] and [5]. 
However, low level of municipal services are detriment to healthy and inadequate citizen satisfaction, Malaysia as a country of different and multifaceted culture and norms, their local government has been through a rapid developmental and infrastructural changes in relations to technological advancement $[3,6]$, yet citizen satisfaction at the local government need to be improved [3]. The effectiveness of municipal services in various local government and councils were ascertained through the local community expression of satisfaction [6]. Citizen satisfactions rely solely on the commitment of the local government. There is connection between municipal service delivery and citizen satisfaction. Therefore, citizen satisfaction and municipal services are key element of local government functionality.

The purpose of this paper is to examine the relationship between quality municipal service delivery and citizen's satisfaction in Malaysian municipal council. This research is important in line with the obvious cross-cultural and awareness differences between citizen satisfaction and municipal service delivery.

Municipal council in Malaysia. The municipal council are accountable in providing public goods and services to every group of people that live within their localities. The greatest contribution provides by the local government is by performing efficient and effective service delivery, predominantly to those who currently have little access or even no access to these services. Therefore, the local authorities in Malaysia power expanded with a complete set of functions and responsibilities within the Local Government Act of 1976. The Local Government Act 1976 (Act 171) empowered the right to embark on varies of tasks and have also merged frameworks for local authorities. The planning powers of local authorities stipulated in the allied Town and Country Planning Act 1976. The Act stated that the local authority shall be the local planning authority for their area, thus, allowing the local authorities to control the developmental functions of urban management and play a more dynamic role in the national development [6]. The functions of local authorities in Malaysia cover on mandatory functions such as the licensing authority, authority for waste and refuse collection and disposal, street lighting and activities pertaining to public health and also discretionary functions that include all development functions such as providing amenities and recreational parks. The major functions of Malaysian local authorities can be summarized as conservational, public, social and developmental [6].

Hypothesis of the study. The study postulates that quality municipal service has direct effects on citizen satisfaction. As shown in the Figure 1.

\section{Quality municipal service}

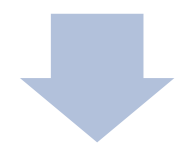

Roads, Parking Space, Town Hall, Drainage system, Refuse collection and disposal, Public toilets, Public transport, Sewage disposal

\section{Citizen satisfaction}

Figure 1 - The relationship between quality municipal service and citizen satisfaction

\section{Materials and Methods}

The method adopted in collecting and analyzing data for this study is as presented in Figure 2.
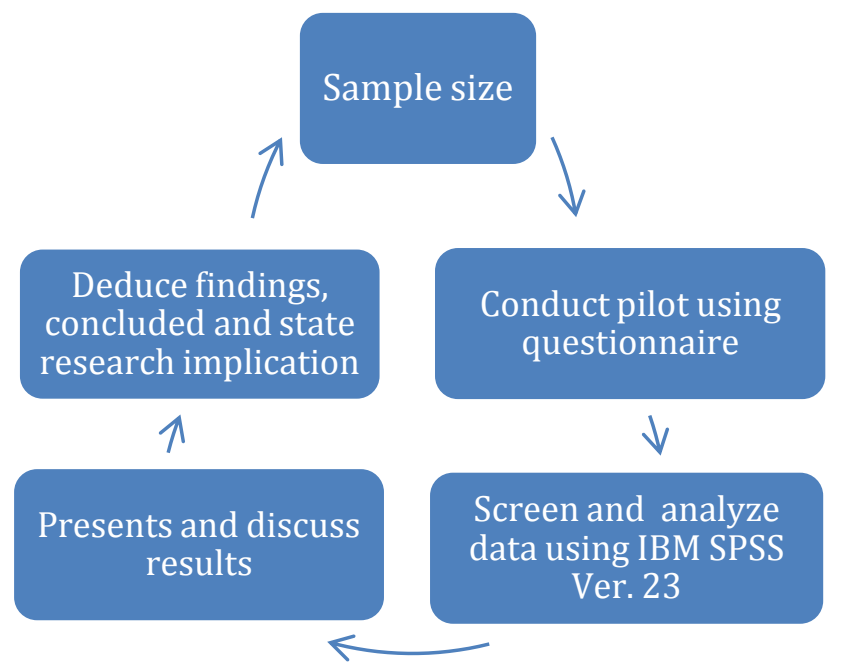

Figure 2 - Research methodology

Structured questionnaires were used as a survey instrument for collecting data in this pilot survey of 100 and 89 were retrieved were from study area. This study applies SPSS statistical tests and 
AMOS version 23 and Structural Equation Modeling (SEM) software was used for further analysis. In order to determine the relationship between the postulated hypotheses of variables of the study that was developed based on previous literature review. These variables that are included in the study have been adopted from the existing literature. Systematic random sampling was used to fetch data of the study. Two variables are under investigation in this study. The statistical measures used in this paper are methodologies recommended by [1], who recommended that minimum sample sizes between 100 and 150 are required to achieve stable MLE results.

\section{Result and Discussion}

From the results of this study, there is significant relationship between quality municipal service and citizen satisfaction. The Figure 3 shows the strength of the relationship. The figure 3 and Table 1 indicate the relationship RMSEA $=0.94$, $\mathrm{GFI}=0.932, \mathrm{NFI}=0.880, \mathrm{CFI}=0.905, \mathrm{TL} 1=0.874$, $\mathrm{ChiS} / \mathrm{df}=4.214$. These values revealed the strong relationship of quality municipal service to citizen satisfaction in order words quality municipal service determines the level of citizen satisfaction.
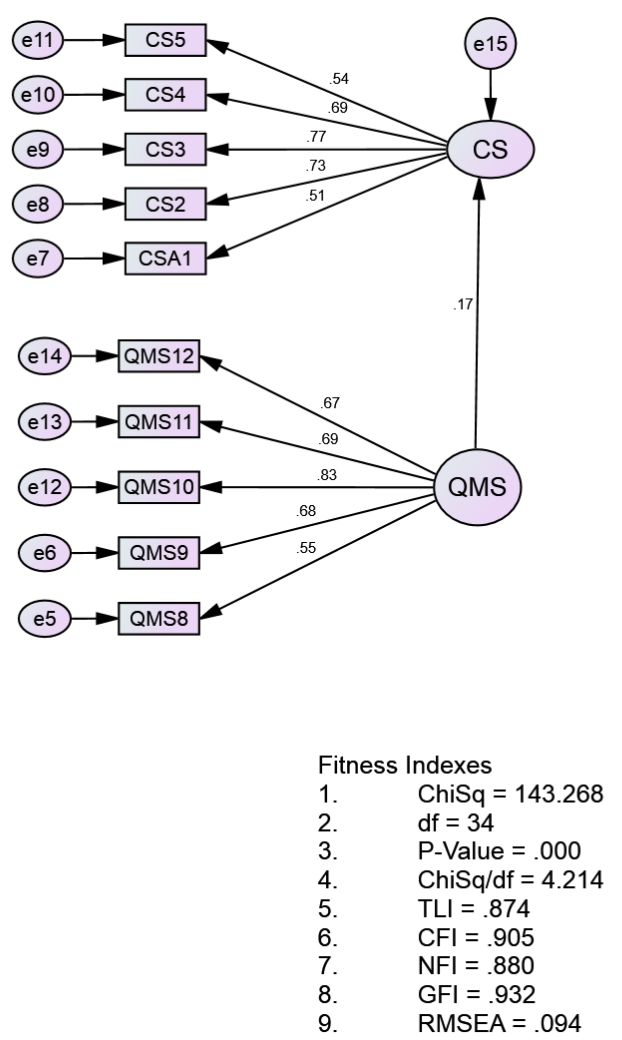

Figure 3 - Structural Model Showing relationship between Quality Municipal service and citizen satisfaction
Table 1 - Regression Weights (Group number 1 Default model)

\begin{tabular}{|l|c|c|c|c|c|}
\hline CS $<-$ & Estimate & S. E. & C. R. & P & Label \\
\cline { 2 - 6 } QMS & .127 & .050 & 2.558 & .011 & Supported \\
\hline
\end{tabular}

Table 1 above reveal that $\beta=0.127, C . R=2.558$ and $\mathrm{p}^{* * *} 0.011$. These values shows that the hypothesis postulated is supported i.e. There is relationship between quality municipal services and citizen satisfaction.

Reliability and Validity of the constructs of the study. The Reliability was assessed using Cronbach $\alpha$, which value was found to be 0.82 for quality municipal service construct and 0.79 was found with community participation construct. These values achieved the required value as suggested by [8] and [1, 2]. All indicator loadings were significantly different from zero and their standardised values were greater than 0.5 . The analysis of variance indicated that there were significant effects of Quality municipal service 0.17 to citizen satisfaction.

\section{Conclusion and Recommendation}

This research study concludes that quality municipal service as a directs effects on citizen satisfaction. The results suggest that local council officials need principally to communicate with and to take into account the comments that are received from the taxpayers who bring forwards their complaint to them. All matters that was needed for enhancing citizen satisfaction should be accorded by the local council. However, the hypothesis that quality municipal service has directs effects on citizen satisfaction was supported. The study also shows that there is significant relationship between quality municipal service and citizen satisfaction. The study gives recommendation that local council should explore more ways to enhance citizen satisfaction.

\section{Acknowledgement}

The corresponding author would like to acknowledge the support and guidance given by his $\mathrm{PhD}$ supervisor and his co-supervisor through constructive criticisms and suggestion in the conduct of the research. The authors are also indebted to the prior literature research that has been made in any anonymous journal referees related to municipal council service delivery. The authors also show their profound gratitude to the Office for Research, Innovation, commercialization and Consultancy management (ORICC) UTHM, Parit Raja, Johor Bahru, Malaysia. 


\section{References}

1. Hair, J. F., Black, W. C., Babin, B. J., \& Anderson, R. E. (2010). Multivariate data analysis: A global perspective (7th ed.). Upper Saddle River: Pearson.

2. Hair, J. F., Black, W. C., Babin, B. J., Anderson, R. E., \& Tatham, R. L. (2006). Multivariate Data Analysis (6th ed.). Upper Saddle River: Pearson Prentice Hall.

3. Kaliannan, A., Puteh, F., \& Dorasamy, M. (2014, August). Measuring service quality in Malaysian local government: the SERVQUAL approach. In Proceedings of Knowledge Management International Conference, Langkawi, Malaysia (pp. 30-34). Langkawi: Sintok College of Art and Sciences, Universiti Utara Malaysia.

4. OECD. (2010). Strategies to Improve Rural Service Delivery. Paris: OECD Pub. doi: 10.1787/9789264083967-en

5. Omar, M. S., Ariffin, H. F., \& Ahmad, R. (2016). Service Quality, Customers' Satisfaction and the Moderating Effects of Gender: A Study of Arabic Restaurants. Procedia - Social and Behavioral Sciences, 224, 384-392. doi: 10.1016/j.sbspro.2016.05.393

6. Osman, M. M., Bachok, S., Bakri, N. I. M., \& Harun, N. Z. (2014). Government Delivery System: Effectiveness of Local Authorities in Perak, Malaysia. Procedia - Social and Behavioral Sciences, 153, 452-462. doi: 10.1016/j.sbspro.2014.10.079

7. Osman, M. M., Jusoh, N. N., Bachok, S., \& Bakri, N. I. (2014). An assessment of local authority performance in delivering their services: Case study of Ipoh City Council. Journal of Architecture, Planning \& Construction Management, 4(2), 58-76.

8. Pallant, J. (2011). SPSS Survival Manual: A step by step guide to data analysis using the SPSS program (4th ed.). Crows Nest: Allen \& Unwin.

9. United Nations. (2017). Sustainable Development Goals. Retrieved April 1, 2017, from http://www.un.org/sustainabledevelopment/health 